\title{
Prenatal cocaine exposure alters alpha2 receptor expression in adolescent rats
}

\author{
Rosemarie M Booze*1,2, David R Wallace ${ }^{3}$, Janelle M Silvers ${ }^{1,2}$, \\ Barbara J Strupp ${ }^{4}$, Diane M Snow ${ }^{5}$ and Charles F Mactutus ${ }^{1}$
}

\begin{abstract}
Address: ${ }^{1}$ Department of Psychology, University of South Carolina Columbia, SC 29208, USA, ${ }^{2}$ Department of Pharmacology, Physiology and Neuroscience, University of South Carolina Columbia, SC 29208, USA, ${ }^{3}$ Department of Pharmacology and Physiology, Oklahoma State University, College of Osteopathic Medicine Tulsa, OK 74017-1898, USA, ${ }^{4}$ Division of Nutritional Sciences and Department of Psychology, Cornell University Ithaca, NY 14853-6301, USA and 5epartment of Anatomy and Neurobiology, The University of Kentucky, Lexington, KY 40536-0298, USA

Email: Rosemarie M Booze* - booze@sc.edu; David R Wallace - walladr@osu-com.okstate.edu; Janelle M Silvers - silversj@gwm.sc.edu; Barbara J Strupp - bjs13@cornell.edu; Diane M Snow - dsnow@uky.edu; Charles F Mactutus - Mactutus@gwm.sc.edu

* Corresponding author
\end{abstract}

Published: 18 April 2006

BMC Neuroscience 2006, 7:33 doi:10.1/86/147|-2202-7-33

This article is available from: http://www.biomedcentral.com/I47/-2202/7/33

(c) 2006 Booze et al; licensee BioMed Central Ltd.

This is an Open Access article distributed under the terms of the Creative Commons Attribution License (http://creativecommons.org/licenses/by/2.0), which permits unrestricted use, distribution, and reproduction in any medium, provided the original work is properly cited.
Received: 06 December 2005

Accepted: 18 April 2006

\begin{abstract}
Background: Prenatal cocaine exposure produces attentional deficits which to persist through early childhood. Given the role of norepinephrine (NE) in attentional processes, we examined the forebrain NE systems from prenatal cocaine exposed rats. Cocaine was administered during pregnancy via the clinically relevant intravenous route of administration. Specifically, we measured $\alpha_{2}$-adrenergic receptor $\left(\alpha_{2}\right.$-AR) density in adolescent (35-days-old) rats, using $\left[{ }^{3} \mathrm{H}\right] \mathrm{R} \times 821002(5$ $n M)$.

Results: Sex-specific alterations of $\alpha_{2}$-AR were found in the hippocampus and amygdala of the cocaine-exposed animals, as well as an upregulation of $\alpha_{2}$-AR in parietal cortex.

Conclusion: These data suggest that prenatal cocaine exposure results in a persistent alteration in forebrain NE systems as indicated by alterations in receptor density. These neurochemical changes may underlie behavioral abnormalities observed in offspring attentional processes following prenatal exposure to cocaine.
\end{abstract}

\section{Background}

Recently, noradrenergic systems have been identified as a potential teratogenic target underlying the functional effects of prenatal cocaine [1-3]. However, information regarding the consequences of prenatal cocaine on the development of noradrenergic receptors is relatively sparse. NE is present early in brain development and regulates important aspects of prenatal brain development, including neural migration and synaptogenesis $[4,5]$. Thus, the ability of cocaine to inhibit NE reuptake has potentially profound effects on the developing nervous system and function of NE systems.

Previous investigations into the effects of prenatal cocaine exposure on catecholaminergic receptors have, for the most part, focused on the long-term effects of exposure on dopaminergic [6-10] and serotonergic [11-14] receptor systems. Fewer studies have examined the noradrenergic receptor family following prenatal cocaine exposure. The neurophysiological effects of NE are mediated by three 
types of receptors: $\alpha_{1}, \alpha_{2}$ and $\beta$. The $\alpha_{2}$ adrenergic receptors are present very early in development, in some brain areas as early as E15 [4]. Prenatal exposure to cocaine has been found to elevate the density of $\alpha_{2}$ adrenergic receptors in the cerebellum and forebrain [15]. Henderson et al [16] reported that cortical $\alpha_{2}$ adrenergic receptor density was unchanged in male rat pups following prenatal cocaine exposure. However, these studies did not differentiate between male and female offspring and used homogenate binding techniques. Moreover, cocaine was administered via the subcutaneous route into the dams, and therefore these effects likely occurred in the presence of potential nutritional and stress confounds [17].

Previous studies from this laboratory and others have demonstrated that the IV route of cocaine administration to pregnant rats produces functional alterations in attentional processes [2,18-21]. Subtle, context-specific sex differences in attentional tasks following prenatal cocaine have been reported in a number of these studies [18-21]. The neurological basis of such attentional deficits is complex and likely mediated by several neurotransmitter systems. Several studies have assessed the involvement of norepinephrine specifically in attentional processes. The development of the heart rate orienting response in preweaning rats, a task used to measure attention to a novel stimus, is dependent upon norepinephrine, but not dopamine or serotonin $[22,23]$. Alterations in the heart rate orienting response of cocaine-treated offspring suggest early impairments in noradrenergic systems $[2,4,18]$. Direct evidence of the effects of cocaine on norepinephrine systems has been provided by Snow et al. [24], in which cocaine was found to directly inhibit process outgrowth in locus coeruleus (LC) neurons.

Altered attention has been reported in 6 year old children gestationally exposed to moderate levels of cocaine [25]. The impairment in automated vigilance task in 6 year olds most likely reflects a deficit in sustained attention and one that also contained an accuracy component (commission vs. omission errors). The NE system is thought to be critically involved in the regulation of attention [26-31]. That is, the activation of NE serves to filter out distracting or competing stimuli and plays a role in selective attention in rats [32]. A recent study reports that rats exposed to prenatal cocaine are more sensitive to impairment of selective attention by idazoxan, an $\alpha 2$ adrenergic receptor agonist [1]. These findings, and reported deficits in vigilance/orienting performance of young rats prenatally exposed to IV cocaine $[2,18]$ suggest that NE plays an important role in attention and in long-term cocaine impairments [19-21]. The mechanisms of cocaineinduced disruption of NE developmental patterns and the relationship between these patterns and the attentional alterations remain to be determined.
For the most part, the effects of prenatal cocaine exposure have been assessed either immediately, during the preweaning period, or long-term, i.e. into mature adulthood. Recently, the adolescent period has been recognized as a period of vulnerability to the effects of drugs of abuse [33]. Exposure to drugs during early development may alter critical neural development, producing longterm effects on sexual maturation and sex-specific behaviors which are manifested during the adolescent period [34,35]. Thus, the adolescent period may represent a unique developmental time frame in which to examine the neurological effects of prenatal drug exposure.

In the present studies we examined potential sex-dependent alterations in $\alpha_{2}$ adrenergic receptor density and function in adolescent rats following prenatal cocaine exposure. The idazoxan derivative, RX821002, was used to detect $\alpha_{2}$ adrenergic receptors. RX821002 is a highly selective antagonist that identifies all the $\alpha_{2}$ adrenergic receptor subtypes with similar affinity [36]. We first used this well-characterized ligand to determine $\alpha_{2}$ receptor density and binding affinity in adolescent rats that received cocaine in utero. We then commenced a more detailed receptor autoradiographic study of the hippocampus, parietal cortex, amygdala, pyriform cortex and hypothalamus to determine whether sex differences in $\alpha_{2}$ receptors were present in adolescent rats prenatally exposed to cocaine. These studies were designed as part of a larger effort to understand the neurobiological basis of the previously reported attentional dysfunction in rats prenatally exposed to cocaine $[1,2,19-21,37]$.

\section{Results \\ Weight/growth parameters}

The mean offspring body weights (on P35) were unaffected by prenatal cocaine exposure. Previous reports have shown that this regimen of in utero cocaine treatment had no effects on maternal weight gain, litter size, gestational length, sex ratio, offspring weight on postnatal day 1 , or pup survival $[1,2,38]$.

\section{$\alpha \mathbf{2 - a d r e n e r g i c ~ r e c e p t o r ~ d e n s i t y : ~ t i s s u e ~ h o m o g e n a t e s ~}$}

Results of tissue homogenate binding studies are displayed in Table 1 and Figure 1. The affinity of RX821002 for $\alpha_{2}$-adrenergic receptors did not differ significantly by sex or prenatal cocaine exposure In all groups, the displacement of [ $\left.{ }^{3} \mathrm{H}\right] \mathrm{RX} 821002$ by unlabeled RX821002 was close to unity $(0.94 \pm 0.05-1.09 \pm 0.16)$ suggesting displacement from a single binding site. Labeling of $\alpha_{2}$ adrenergic receptors by $\left[{ }^{3} \mathrm{H}\right] \mathrm{RX} 821002$ was sex-dependent within the saline group with females displaying $36.2 \%$ higher density of $\alpha_{2}$-adrenergic receptors than males. The number of $\alpha_{2}$-adrenergic receptors labeled with $2.0 \mathrm{nM}$ $\left[{ }^{3} \mathrm{H}\right] \mathrm{RX} 821002$ following prenatal cocaine exposure was significantly increased $[\mathrm{F}(1,20)=5.0 ; P \leq 0.04)$ in both 
Table I: Competition analysis (cold saturation) of $\left[{ }^{3} \mathrm{H}\right] \mathrm{R} \times 82 \mathrm{I} 1002$ sites in hippocampal homogenates from male and female pups that were exposed to IV saline or cocaine in utero. (Means \pm SEM). $n=14$ per group.

\begin{tabular}{lllcc}
\hline & & $\mathrm{K}_{\mathrm{d}}(\mathrm{nM})$ & $\mathrm{B}_{\operatorname{MAX}}(\mathrm{fmol} / \mathrm{mg}$ protein) & $\mathrm{n}_{\mathrm{H}}$ \\
\hline CONTROL & Male & $0.8 \pm 0.1$ & $84.8 \pm 14.1$ & $0.94 \pm 0.05$ \\
& Female & $1.3 \pm 0.6$ & $115.4 \pm 10.7$ & $0.97 \pm 0.09$ \\
COCAINE & Male & $0.8 \pm 0.1$ & $134.1 \pm 16.7$ & $0.98 \pm 0.11$ \\
& Female & $1.2 \pm 0.2$ & $125.3 \pm 10.7$ & $1.09 \pm 0.16$
\end{tabular}

males and females. This effect was most profound in cocaine-exposed males, as they exhibited a $58.1 \%$ increase in $\alpha_{2}$-adrenergic receptor density, relative to saline treated males $[\mathrm{F}(1,20)=6.9 ; P \leq 0.02)$. Thus, prenatal cocaine produced alterations in $\alpha_{2}$-adrenergic receptor density in the hippocampus without changes in binding affinity.

\section{$\alpha \mathbf{2}$-adrenergic receptor density: autoradiography}

Representative $\left[{ }^{3} \mathrm{H}\right] \mathrm{RX} 821002$ autoradiograms are depicted in Figure 2. Tissue sections incubated with $2 \mathrm{nM}$ $\left[{ }^{3} \mathrm{H}\right] \mathrm{RX} 821002$ exhibited both sex- and cocaine-induced alterations in $\alpha_{2}$-adrenergic receptor density. Following prenatal exposure to cocaine, the density of $\alpha_{2}$-adrenergic receptors demonstrated a significant interaction between region, sex and cocaine $[\mathrm{F}(4,208)=4.7 ; P \leq 0.007]$. The binding of $\left[{ }^{3} \mathrm{H}\right] \mathrm{RX} 821002$ to $\alpha_{2}$-adrenergic receptors exhibited significant differences between region and sex within the saline group $[\mathrm{F}(4,208)=10.2 ; P \leq 0.0001]$. Prenatal cocaine exposure significantly affected the den-

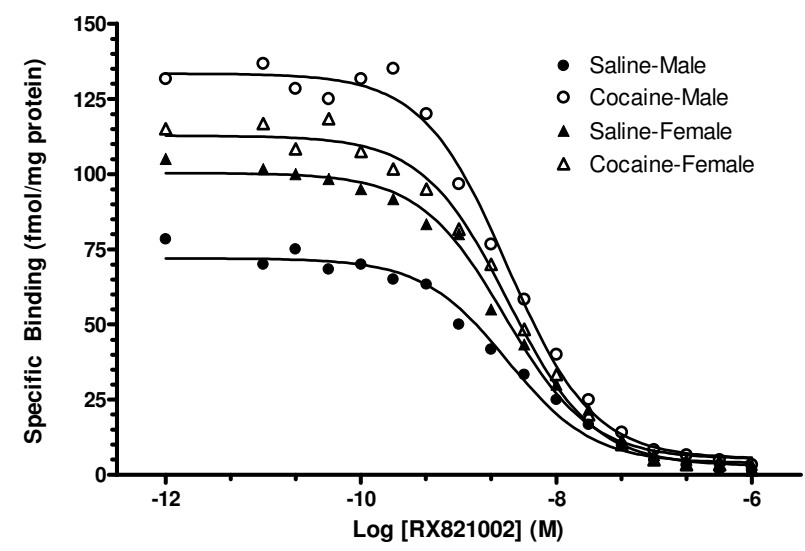

Figure I

Representative competition ("cold saturation") analysis curve measured in hippocampus from male and female offspring exposed to cocaine in utero. Analysis was performed by the addition of $2 \mathrm{nM}\left[{ }^{3} \mathrm{H}\right] \mathrm{R} \times 821002$ added to tubes containing unlabeled RX82 I002 (I pM - I $\mu \mathrm{M}$ ) or $10 \mu \mathrm{M}$ phentolamine (nonspecific binding). Data were best fit to a single-site model with hill slopes $\left(n_{H}\right)$ approaching unity. Calculated $K_{d}$ and $B_{\text {MAX }}$ values are expressed in Table $I$. sity of $\alpha_{2}$-adrenergic receptors in male rats across the regions examined $[\mathrm{F}(4,208)=4.0 ; P \leq 0.01]$.

In control animals prenatally exposed to saline, the density of hippocampal CA1 $\alpha_{2}$-adrenergic receptors in female rats was significantly $[\mathrm{F}(1,52)=23.2 ; P \leq 0.001]$ higher than the density of $\alpha_{2}$-adrenergic receptors observed in male controls (Figure 3 ). In the area CA1 of the hippocampus, a significant interaction between drug treatment and sex was observed $[\mathrm{F}(1,52)=20.00 ; P \leq$ $0.001]$. Similar to tissue homogenates, laconosum-moleculare layer of area CA1 hippocampal $\alpha_{2}$-adrenergic receptors were upregulated $21 \%$ in male offspring following cocaine exposure $[\mathrm{F}(1,52)=6.8 ; \mathrm{P}<0.01]$, whereas $\alpha_{2}$ adrenergic receptors did not significantly differ in females.

Of the other brain regions examined, only the parietal cortex and central nucleus of the amygdala exhibited alterations in $\alpha_{2}$-adrenergic receptor density following prenatal cocaine exposure. In the parietal cortex, a significant effect of drug was observed $[\mathrm{F}(1,52)=4.1 ; P \leq 0.05]$, with no effect of sex or interaction between sex and prenatal drug treatment (Figure 4). In the amygdala, the density of $\alpha_{2}$ adrenergic receptors was significantly $[\mathrm{F}(1,52)=10.9 ; P \leq$ 0.002] higher in males compared to females from the saline group (Figure 5). Prenatal cocaine exposure increased the number of $\alpha_{2}$-adrenergic receptors in the amygdala from female rats compared to saline treated females $[F(1,52)=7.2 ; P \leq 0.01]$ such that the density of $\alpha_{2}$-adrenergic receptors in this region was similar to the density observed in male rats (Figure 5). There were no effects of either sex or prenatal drug exposure on the density of $\alpha_{2}$-adrenergic receptors in either the pyriform cortex or periventricular nucleus of the hypothalamus.

\section{Discussion}

The present study found alterations in $\alpha_{2}$ adrenergic receptor density in the adolescent brain subsequent to prenatal cocaine exposure. Adolescence represents a period of vulnerability for substance abuse and age-dependent sensitivity to drugs. Receptor alterations expressed during adolescence may modify essential transitions necessary for producing normal adult brain function [39]. Prenatal IV cocaine exposure appears to alter normal development of the NE receptor systems, leading to altered adolescent NE brain systems.

In general, catecholamine receptor density and function appear to be particularly plastic during the adolescent period. For example, dopamine D1 and D2 receptors are overproduced and eliminated (over $40 \%$ ) in male rats during adolescence [40]. The distribution of $\alpha 2$ adrenergic receptors has been reported to generally resemble adult patterns by P28 [41]; however, functional studies have demonstrated decreased depolarized release of $\mathrm{NE}$ 


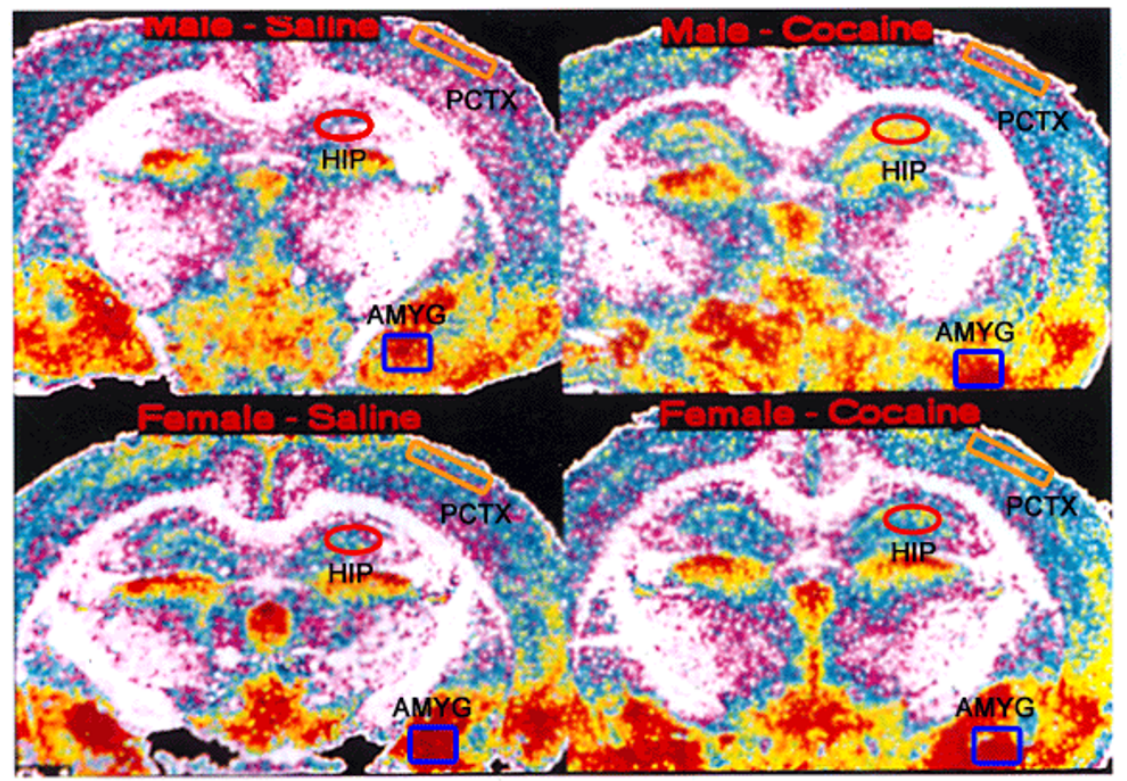

\section{Figure 2}

Representative false-color (RGB) autoradiograms of $\left[{ }^{3} \mathrm{H}\right] \mathrm{R} \times 821002$ binding density in brain slices from adolescent males and females exposed to either saline or cocaine in utero. Areas of low binding density appear white to light purple, areas of moderate binding appear blue to yellow, and areas of high binding density appear dark red. Measurements were taken from hippocampus (stratum lacunosum-moleculare of CAI near the hippocampal fissure, as approximately marked by a red oval), parietal cortex (layer II, as approximately marked by an orange rectangle), and amygdala (central nucleus, as approximately marked by a blue square).

and a greater capacity for NE reuptake in the hypothalamus (with a potential shift in hypothalamic alpha receptor subtype) is present in rats during the adolescent period [42]. Sex differences in NE content have also been reported in several brain regions in adolescent animals (P33) [43]. Prenatal cocaine exposure has been shown to result in increased levels of NE in the preoptic region of male, but not female, adult rats [44]. Previous reports of $\alpha 2$ adrenergic receptor distribution used pooled male and female rat brains without presenting statistical analysis on sex differences [41]. Furthermore, the number of animals used from each litter was unclear. Therefore the current studies are the first to report baseline sex differences in $\alpha 2$ adrenergic receptor density in adolescent animals, as well as alterations in density related to prenatal cocaine exposure in this age group.

Prenatal cocaine exposure may alter $\alpha 2$ adrenergic receptors density by affecting development of the LC. The entire $\mathrm{NE}$ input to the rat hippocampus is provided by LC neurons, primarily from the dorsal one-third of the LC $[45,46]$. In early LC development, approximately $7 \%$ of the neurons are generated on GD11, 75\% on GD12 and $18 \%$ on GD13 [47]. LC neurons and their processes synthesize NE as early as 12-14 days gestation [48] well before synaptogenesis is underway in the terminal fields. Efferent LC fibers first appear in the neocortical terminal fields on GD16 and these fibers are proposed to play a major role in induction and differentiation of neural tissue [49]. Hippocampal neurons are generated three days after the LC neurons [48]. The late gestational period of the rat is distinguished by continued fiber organization and ramification in the LC terminal fields [50]. A recent study, using the same cocaine dose and route of administration used in the current study, demonstrated that prenatal cocaine exposure during the development of LC neurons inhibits the growth of LC neuritis [24]. Cocaine binding sites are evident in the fetal brain as early as GD15 and by GD20 the Kd of $\left[{ }^{3} \mathrm{H}\right]$ cocaine binding is similar to the Kd values observed in adulthood [51]. Thus, our prenatal cocaine exposure covers the period of LC neuronal genesis and NE axonal proliferation in the terminal fields, during which time these systems are sensitive to disruption by cocaine.

Adolescent brain development may represent a critical developmental stage in which prenatal cocaine effects may be expressed in a sex-dependent manner. Our findings of $\alpha_{2}$ adrenergic receptor upregulation in male rat hippocampus may be a compensatory response to 


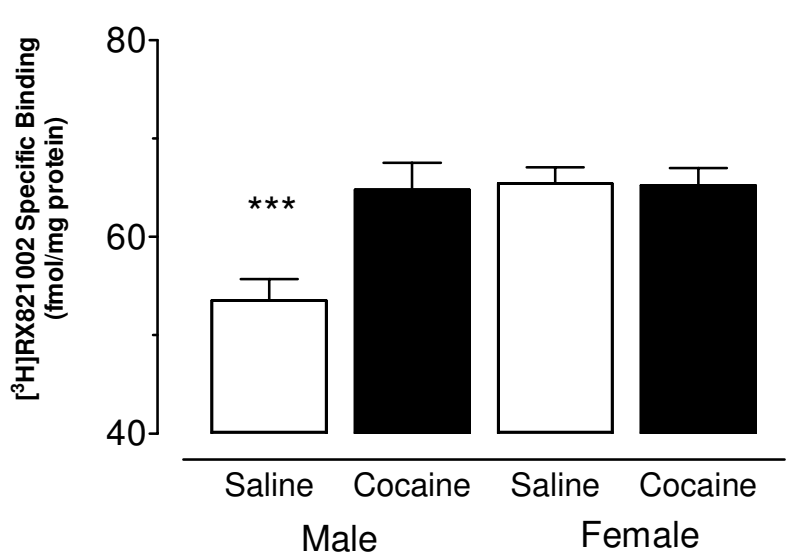

Figure 3

Density of $\alpha_{2}$-adrenergic receptors in laconosum-moleculare layer of hippocampal area CAI as measured by autoradiography. Data are expressed as mean density ( \pm S.E.M.). In control animals prenatally exposed to saline, the density of hippocampal CAI $\alpha_{2}$-adrenergic receptors in male rats was significantly $[F(I, 52)=23.2 ; P<0.000 I]$ lower than the density of $\alpha_{2}$-adrenergic receptors observed in female controls. Prenatal cocaine exposure abolished this sex difference in hippocampal $\alpha_{2}$-adrenergic receptors by increasing binding $21 \%$ in male offspring, whereas $\alpha_{2}$-adrenergic receptors did not significantly differ by drug exposure in females. $n=14$ per group.

cocaine-mediated increases in norepinephrine concentration during prenatal development. Interestingly, female offspring did not show a similar robust increase in $\alpha_{2}$ adrenergic receptor density in the hippocampus. However, in the amygdala the $\alpha_{2}$ adrenergic receptors were increased in females subsequent to prenatal cocaine exposure. In other regions such as the pyriform cortex, no changes attributable to cocaine were found. Our findings suggest sex-specific expression of cocaine-mediated alterations displayed in adolescence. Sex-specific alterations in receptor density may be restricted to particular brain regions, differ in directionality, and may not reflect global brain alterations.

\section{Conclusion}

In summary, IV exposure of pregnant rats to cocaine produced persistent, sex-specific alterations in the NE systems of adolescent offspring. Disruption of forebrain NE systems during the prenatal period might be the neurobiological basis for a number of functional disturbances occurring as a consequence of prenatal cocaine exposure.

\section{Methods}

\section{Animals}

Nulliparous female Sprague-Dawley rats were obtained from Harlan Sprague-Dawley, Inc. (Indianapolis, IN) at

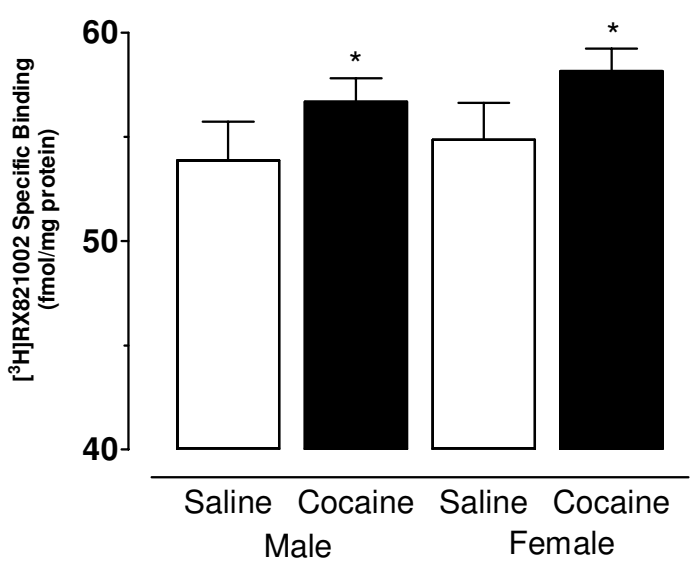

Figure 4

Density of $\alpha 2$ adrenergic receptors in parietal cortex (layer II) as measured by autoradiography. Data are expressed as mean density $( \pm$ S.E.M.). In the parietal cortex, prenatal cocaine exposure increased $\alpha 2$ adrenergic receptors in both sexes $[F(I, 52)=4.1 ; P<0.05] . n=14$ per group.

approximately 10-12 weeks of age (225-249 g), placed into quarantine for one week and subsequently moved to the animal colony. The animals were maintained according to NIH guidelines in AAALAC accredited facilities. Food (Pro-Lab Rat, Mouse, Hamster Chow No. 3000) and water were available ad libitum. The animal colony was maintained at $21 \pm 2{ }^{\circ} \mathrm{C}$ and $50 \pm 10 \%$ relative humidity and a $12 \mathrm{hr}$ light: $12 \mathrm{hr}$ dark cycle with lights on at 07:00 h (EST).

\section{Surgery}

Half of the animals were surgically implanted with vascular catheters (as described below) and the remaining animals served as surrogate dams for the prenatal vehicle and cocaine treated pups. Catheterization was performed as previously described [38]. In brief, the animals were anesthetized with a mixture of ketamine hydrochloride (100 $\mathrm{mg} / \mathrm{kg} / \mathrm{ml})$ and xylazine $(3.3 \mathrm{mg} / \mathrm{kg} / \mathrm{ml})$ and a sterile Intracath IV catheter with a Luer-lock injection cap (Medex) was implanted dorsally in a subcutaneous pouch. The distal end of the catheter was inserted into the left jugular vein and advanced towards the heart. Animals were kept under periodic postoperative observation and returned to the vivarium upon recovery from anesthesia. Beginning on the day following surgery, the catheters were flushed daily with approximately $0.2 \mathrm{ml}$ of $2.5 \%$ heparinized saline. The animals were observed for any signs of discomfort or behavioral distress. Complete anesthesia, surgical, recovery and postoperative records were maintained for each animal. 


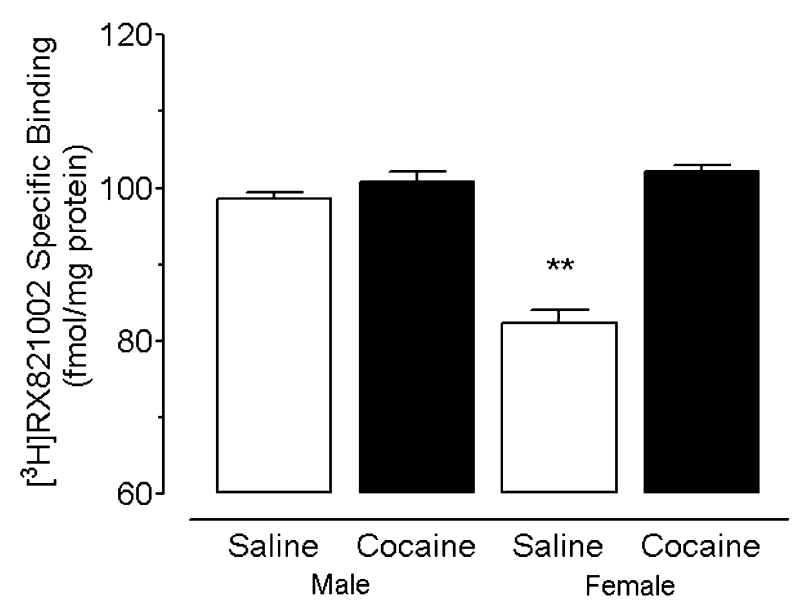

\section{Figure 5}

Density of $\alpha_{2}$-adrenergic receptors in amygdala (central nucleus) as measured by autoradiography. In control animals, the density of $\alpha_{2}$-adrenergic receptors was significantly lower $[F(I, 52)=10.9 ; P<0.01]$ in females than the density of $\alpha_{2-}$ adrenergic receptors observed in male controls. Prenatal cocaine exposure abolished this sex difference in amygdala $\alpha_{2}$-adrenergic receptors by increasing binding by $19 \%$ in female offspring, whereas $\alpha_{2}$-adrenergic receptors did not significantly differ because of cocaine exposure in males. $n=$ 14 per group.

\section{Animal mating}

At 10-12 days following surgery, the females were group housed with males for breeding. Females were checked daily for vaginal cytology and the presence of sperm. Sperm positive females were considered at gestation day 0 (GD0) and individually housed in plastic cages with Sanichip $^{\mathrm{TM}}$ bedding throughout pregnancy and lactation.

\section{Drug treatment}

The catheterized, pregnant animals were randomly assigned to one of two groups that received either saline or $3.0 \mathrm{mg} / \mathrm{kg}$ cocaine. This dose of cocaine, delivered IV, was chosen based on reports that 1) it produces a peak arterial level in the male rat not significantly different from peak levels following administration of $32 \mathrm{mg}$ of cocaine IV to humans $[52,53], 2)$ the acute heart rate and blood pressure responses in late gestation pregnant rats are similar to those produced in a variety of other species (dog, monkey, humans; [54]), and 3) under experimental conditions, this dose is self-administered by users multiple times in a $2.5 \mathrm{hr}$ session [55] Cocaine was administered as an IV bolus injection delivered in a volume of 1.0 $\mathrm{ml} / \mathrm{kg}$ (15 sec) followed by flushing (15 sec) with $0.2 \mathrm{ml}$ heparinized $(2.5 \%)$ saline (i.e., the approximate volume of the catheter). Surrogate dams received neither drug treatment nor the daily handling associated with drug treatment. Cocaine and saline injections were administered 1x day from GD8-GD14 and 2x day from GD15GD21.

\section{Offspring treatment}

All pregnant rats were checked twice daily for pups. Day of birth was defined as postnatal day 0 (P0). On P1, litters were weighed and culled to 8 pups with an equal number of males and females. Each pup was tattooed for identification and the culled litters of all catheterized dams were fostered to surrogate dams that had delivered within $24 \mathrm{~h}$. Thus, no pups were raised by their biological mother or exposed to drug during the postnatal period. Pups were reared in their surrogate mothers' cage until weaning at P21, at which time offspring were group housed in same sex pairings. One male and one female from each litter were sacrificed on P35 for homogenate binding and autoradiographic analysis. Thus, each experiment included pups from 14 different litters.

\section{$\alpha 2$-adrenergic receptor homogenate binding}

Hippocampal tissue was collected for $\alpha_{2}$-adrenergic receptor binding from one male and one female from each litter on P35. Animals were killed by rapid decapitation and the brains removed. The hippocampi were dissected and immediately frozen in liquid nitrogen. Frozen hippocampal tissue was weighed and homogenized in 20 volumes/ weight ice-cold $25 \mathrm{mM}$ glycylglycine (GLYGLY) buffer $(\mathrm{pH}=7.6)$. Crude homogenates were centrifuged at $20,000 \mathrm{X}$ for $15 \mathrm{~min}$ at $4^{\circ} \mathrm{C}$. The pellet was resuspended in 200 volumes $25 \mathrm{mM}$ GLYGLY buffer $(\mathrm{pH}=7.6)$ and the resulting crude membrane preparation was used for binding assays at a final protein content of approximately 0.6$0.7 \mathrm{mg} / \mathrm{ml}$. Protein contents were determined by the Bradford [56] method (BioRad, Richmond, CA).

Cold saturation homogenate binding assays were performed as previously described [36]. Briefly, for the binding of $\left[{ }^{3} \mathrm{H}\right] \mathrm{RX} 821002$ (58 Ci/mmol; Amersham, Arlington Heights, IL), $50 \mu \mathrm{l}$ of labeled drug ( $2 \mathrm{nM}$ ) and $50 \mu \mathrm{l}$ of assay buffer containing one of seventeen concentrations $\left(10^{-12}\right.$ to $\left.10^{-6}\right)$ of unlabeled RX821002 were added together and allowed to equilibrate to room temperature $\left(22^{\circ} \mathrm{C}\right)$. Binding was initiated by addition of $900 \mu \mathrm{l}$ of tissue (0.6-0.7 $\mathrm{mg}$ of protein) and allowed to incubate to equilibrium at $22^{\circ} \mathrm{C}$ for $60 \mathrm{~min}$. Nonspecific binding was defined as $\left[{ }^{3} \mathrm{H}\right] \mathrm{RX} 821002$ bound in the presence of $10 \mu \mathrm{M}$ phentolamine. Binding was terminated by filtration under reduced pressure with a Brandel Tissue Harvestor (Gaithersburg, MD) followed by a $15 \mathrm{sec}$ wash with icecold GLYGLY buffer onto GF/B glass fiber filters that had been presoaked for 2 hours with buffer containing $0.3 \%$ polyethyleneimine. Filters were dried overnight and analysis of radioligand bound was accomplished by scintillation spectrophotometry (40-50\% efficiency). 


\section{$\alpha$-adrenergic receptor autoradiography}

For preparation of tissue sections, animals were killed by rapid decapitation and the brains were carefully removed from the cranium, blocked and immediately frozen on powdered dry ice. The frozen tissue blocks were cryostatsectioned $\left(-20^{\circ} \mathrm{C}, 20 \mu \mathrm{m}\right.$ thick) in the standard coronal plane. Sections were collected at $-3.3-3.8 \mathrm{~mm}$ relative to Bregma (plates 31-33 in Paxinos and Watson, [57]). Two additional adjacent sections were collected either for Nissl staining or acetylcholinesterase (AchE) staining [58] to aid in identification of the subregional structures. All sections were stored desiccated at $-80^{\circ} \mathrm{C}$ prior to processing.

Frozen tissue sections were thawed and brought to room temperature $\left(22^{\circ} \mathrm{C} ; 5 \mathrm{~min}\right)$ followed by preincubation in $25 \mathrm{mM}$ GLYGLY buffer ( $\mathrm{pH}=7.6$ ) for $5 \mathrm{~min}$. Slides were transferred into incubation vials containing $2 \mathrm{nM}$ $\left[{ }^{3} \mathrm{H}\right] \mathrm{RX} 821002$ and incubated at $22^{\circ} \mathrm{C}$ for $90 \mathrm{~min}$. Nonspecific binding was defined by $10 \mu \mathrm{M}$ phentolamine. Binding was terminated by transfer of slides into $4^{\circ} \mathrm{C}$ buffer and washing $2 \times 2 \mathrm{~min}$. Slides were then quickly rinsed in $4^{\circ} \mathrm{C}$ distilled water to remove buffer salts, dried under a stream of cool air and stored desiccated overnight under vacuum. Dried, labeled, tissue sections and $\left[{ }^{3} \mathrm{H}\right]$ microscales (Amersham, Arlington, IL) were exposed to tritium sensitive film (Hyperfilm, Amersham) for 14 days at room temperature in light-tight X-ray film cassettes. Films were developed using Kodak D-19 developer and Kodak rapid fixer.

Autoradiographic images were examined using the MCID4 computerized image analysis system (Imaging Research, Ontario, Canada). The use of adjacent Nissl and AChE stained slides allowed for the determination of [ $\left.{ }^{3} \mathrm{H}\right] \mathrm{RX} 821002$ binding in specific subregions of the hippocampus (stratum lacunosum-moleculare of CA1 near the hippocampal fissure). Binding density was also determined for the parietal cortex (layer II), amygdala (central nucleus), pyriform cortex (layer II-III) and hypothalamus (periventricular nucleus). These brain regions have high levels of $\alpha_{2}$ adrenergic receptors [59]. Adjacent sections, incubated with $10 \mu \mathrm{M}$ phentolamine (nonspecific binding; $<10 \%$ total binding), were aligned with total binding sections and digitally subtracted to obtain "specific" binding images. Regional optical density data are expressed as $\mathrm{fmol} / \mathrm{mg}$ weight $[60,61]$.

\section{Data analysis}

Data were examined by ANOVA ([62]; BMDP statistical software, release 7, Los Angeles, CA, 1993). The Greenhouse-Geiser df correction factor was used for violations of compound symmetry [63]. An $\alpha$ level of $p<0.05$ was the significance level set for rejection of the null hypothesis. Analysis of $\mathrm{K}_{\mathrm{D}}$ and $\mathrm{B}_{\mathrm{MAX}}$ values were determined using the GraphPAD-PRISM nonlinear curve fitting program (GraphPAD, San Diego, CA).

\section{Chemicals}

Cocaine $\mathrm{HCl}$ was purchased from Sigma Chemical Co. (St. Louis, MO) and was dissolved in sterile isotonic saline at the indicated concentrations based on the weight of the salt. All cocaine solutions were prepared immediately prior to use in a volume of $1 \mathrm{ml} / \mathrm{kg}$. All other buffer chemicals were obtained from Sigma Chemical Co.

\section{Authors' contributions}

$\mathrm{RMB}$ was responsible for the conception and design of the study, interpretation of the data, and drafting the manuscript. DRW participated in the conception and design of the study and carried out the binding studies. JMS participated in data analysis and manuscript preparation. BJS and DMS participated in the conception and interpretation of the study. CFM was responsible for experimental design, statistical analyses, data interpretation and drafting the manuscript. All authors read and approved the final manuscript.

\section{Acknowledgements}

This work was supported in part by grants from the National Institute of Health (DA0I37R, DA0I440I (RMB), DA0I3965 (BJS), DA0I 2719 (DMS), DA009160, and HD043680 (CFM)). The authors gratefully acknowledge the assistance of M.A. Welch in conduct of the experiments, C. L. Land for critical evaluation of the manuscript, and P. Olton for graphical preparation.

\section{References}

I. Bayer LE, Kakumanu S, Mactutus CF, Booze RM, Strupp BJ: Prenatal cocaine exposure alters sensitivity to the effects of idazoxan in a distraction task. Behav Brain Res 2002, 133:185-196.

2. Mactutus CF: Prenatal intravenous cocaine adversely affects attentional processing in preweanling rats. Neurotoxicol Teratol 1999, 2 |:539-550.

3. Snow DM, Smith JD, Booze RM, Welch MA, Mactutus CF: Cocaine decreases cell survival and inhibits neurite extension of rat locus coeruleus neurons. Neurotoxicol Teratol 200I, 23:225-234.

4. Winzer-Serhan UH, Raymon HK, Broide RS, Chen Y, Leslie FM: Expression of alpha 2 adrenoceptors during rat brain development-I. Alpha 2A messenger RNA expression. Neuroscience 1997, 76:24I-260.

5. Winzer-Serhan UH, Leslie FM: Expression of alpha2A adrenoceptors during rat neocortical development. J Neurobiol 1999 , 38:259-269.

6. Du W, Aloyo VJ, Pazdelski PS, Harvey JA: Effects of prenatal cocaine exposure on amphetamine-induced dopamine release in the caudate nucleus of the adult rabbit. Brain Res 1999, 836:194-198.

7. Jones LB, Stanwood GD, Reinoso BS, Washington RA, Wang HY, Friedman $E$, et al:: In utero cocaine-induced dysfunction of dopamine DI receptor signaling and abnormal differentiation of cerebral cortical neurons. Neurosci 2000, 20:4606-46I4.

8. Salvatore MF, Hudspeth O, Arnold LE, Wilson PE, Stanford JA, Mactutus CF, et al.: Prenatal cocaine exposure alters potassiumevoked dopamine release dynamics in rat striatum. Neuroscience 2004, I 23:48|-490.

9. Stewart CW, Scalzo FM, Valentine J, Holson RR, Ali SF, Slikker W Jr: Gestational exposure to cocaine or pharmacologically related compounds: effects on behavior and striatal dopamine receptors. Life Sci 1998, 63:2015-2022.

10. Wang HY, Runyan S, Yadin E, Friedman E: Prenatal exposure to cocaine selectively reduces DI dopamine receptor-medi- 
ated activation of striatal Gs proteins. J Pharmacol Exp Ther 1995, 273:492-498.

II. Battaglia G, Cabrera-Vera TM, Van De Kar LD: Prenatal cocaine exposure potentiates $5-\mathrm{HT}(2 \mathrm{a})$ receptor function in male and female rat offspring. Synapse 2000, 35:163-172.

12. Bolanos CA, Trksak GH, Glatt SJ, Jackson D: Prenatal cocaine exposure increases serotonergic inhibition of electrically evoked acetylcholine release from rat striatal slices at adulthood. Synapse 2000, 36: I-II.

13. Johns JM, Lubin DA, Lieberman JA, Lauder JM: Developmental effects of prenatal cocaine exposure on 5-HTIA receptors in male and female rat offspring. Dev Neurosci 2002, 24:522-530.

14. Meyer JS, Shearman LP, Collins LM: Monoamine transporters and the neurobehavioral teratology of cocaine. Pharmacol Biochem Behav 1996, 55:585-593.

15. Seidler FJ, Slotkin TA: Fetal cocaine exposure causes persistent noradrenergic hyperactivity in rat brain regions: effects on neurotransmitter turnover and receptors. J Pharmacol Exp Ther 1992, 263:4|3-42|.

16. Henderson MG, McConnaughey MM, McMillian BA: Long-term consequences of prenatal exposure to cocaine or related drugs: effects on rat brain monoamine receptors. Brain Res Bull I99I, 29:94I-945.

17. Spear LP, Silveri MM, Casale M, Katovic NM, Campbell JO, Douglas LA: Cocaine and development: a retrospective perspective. Neurotoxicol Teratol 2002, 24:321-327.

18. Foltz TL, Snow DM, Strupp BJ, Booze RM, Mactutus CF: Prenatal intravenous cocaine and the heart rate-orienting response: a dose-response study. Int J Dev Neurosci 2004, 22:285-296.

19. Garavan H, Morgan RE, Mactutus CF, Levitsky DA, Booze RM, Strupp $B$ ]: Prenatal cocaine exposure impairs selective attention: evidence from serial reversal and extradimensional shift tasks. Behav Neurosci 2000, I | 4:725-738.

20. Gendle MH, Strawderman MS, Mactutus CF, Booze RM, Levitsky DA, Strupp BJ: Impaired sustained attention and altered reactivity to errors in an animal model of prenatal cocaine exposure. Brain Res Dev Brain Res 2003, 147:85-96.

21. Gendle MH, White TL, Strawderman M, Mactutus CF, Booze RM, Levitsky DA, et al:: Enduring effects of prenatal cocaine exposure on selective attention and reactivity to errors: evidence from an animal model. Behav Neurosci 2004, I 1 8:290-297.

22. Saiers JA, Campbell BA: Disruption of noradrenergic, but not serotonergic or opiate, functioning blocks both cardiac and behavioral components of the orienting response in preweanling rats. Behav Neural Biol 1990, 54:254-270.

23. Saiers JA, Richardson R, Campbell BA: Disruption and recovery of the orienting response following shock or context change in preweanling rats. Psychophysiology 1990, 27:45-56.

24. Snow DM, Carman HM, Smith JD, Booze RM, Welch MA, Mactutus CF: Cocaine-induced inhibition of process outgrowth in locus coeruleus neurons: role of gestational exposure period and offspring sex. Int J Dev Neurosci 2004, 22:297-308.

25. Richardson GA, Conroy ML, Day NL: Prenatal cocaine exposure: effects on the development of school-age children. Neurotoxicol Teratol 1996, 18:627-634.

26. Aston-Jones G, Bloom FE: Nonrepinephrine-containing locus coeruleus neurons in behaving rats exhibit pronounced responses to non-noxious environmental stimuli. I Neurosci I98I, I:887-900.

27. Aston-Jones G, Rajkowski J, Kubiak P, Alexinsky T: Locus coeruleus neurons in monkey are selectively activated by attended cues in a vigilance task. I Neurosci 1994, 14:4467-4480.

28. Clark CR, Geffen GM, Geffen LB: Catecholamines and attention. II: Pharmacological studies in normal humans. Neurosci Biobehav $\operatorname{Rev}$ 1987, II:353-364.

29. Clark CR, Geffen GM, Geffen LB: Catecholamines and attention. I: Animal and clinical studies. Neurosci Biobehav Rev 1987 I I:34I-352.

30. Mason ST: Noradrenaline and selective attention: a review of the model and the evidence. Life Sci 1980, 27:617-63I.

31. Olpe H, Steinman MW, Jones RSG: Electrophysiological perspectives on locus coeruleus: Its role in cognitive versus vegetative functions. Physiol Psychol 1985, 13:179-187.

32. Bunsey MD, Strupp BJ: Specific effects of idazoxan in a distraction task: evidence that endogenous norepinephrine plays a role in selective attention in rats. Behav Neurosci 1995, 109:903-911.

33. Tirelli E, Laviola G, Adriani W: Ontogenesis of behavioral sensitization and conditioned place preference induced by psychostimulants in laboratory rodents. Neurosci Biobehav Rev 2003, 27:163-178.

34. Spear LP: The adolescent brain and age-related behavioral manifestations. Neurosci Biobehav Rev 2000, 24:417-463.

35. Wood RD, Spear LP: Prenatal cocaine alters social competition of infant, adolescent, and adult rats. Behav Neurosci 1998, I | 2:4|9-43|

36. Wallace DR, Muskardin DT, Zahniser NR: Pharmacological characterization of $[3 \mathrm{H}]$ idazoxan, $[3 \mathrm{H}] \mathrm{R} \times 821002$ and $\mathrm{p}$ [ 1251$]$ iodoclonidine binding to alpha 2-adrenoceptors in rat cerebral cortical membranes. Eur J Pharmacol 1994, 258:67-76.

37. Bayer LE, Brown A, Mactutus CF, Booze RM, Strupp BJ: Prenatal cocaine exposure increases sensitivity to the attentional effects of the dopamine D I agonist SKF8 I 297. J Neurosci 2000 20:8902-8908.

38. Mactutus CF, Herman AS, Booze RM: Chronic intravenous model for studies of drug (Ab)use in the pregnant and/or grouphoused rat: an initial study with cocaine. Neurotoxicol Teratol 1994, 16:|83-19|.

39. Andersen SL: Stimulants and the developing brain. Trends Pharmacol Sci 2005, 26:237-243.

40. Andersen SL, Rutstein M, Benzo JM, Hostetter JC, Teicher MH: Sex differences in dopamine receptor overproduction and elimination. Neuroreport 1997, 8: 1495-I498.

4I. Happe HK, Coulter CL, Gerety ME, Sanders JD, O'Rourke M, Bylund $\mathrm{DB}$, et al.: Alpha-2 adrenergic receptor development in rat CNS: an autoradiographic study. Neuroscience 2004, 123:167-178.

42. Choi S, Kellogg CK: Adolescent development influences functional responsiveness of noradrenergic projections to the hypothalamus in male rats. Brain Res Dev Brain Res 1996, 94:|44-|5|.

43. Vathy I, Rimanoczy A, Eaton RC, Katay L: Sex dimorphic alterations in postnatal brain catecholamines after gestational morphine. Brain Res Bull 1995, 36:185-193.

44. Vathy I, Katay L, Mini KN: Sexually dimorphic effects of prenatal cocaine on adult sexual behavior and brain catecholamines in rats. Brain Res Dev Brain Res 1993, 73: I I 5-122.

45. Mason ST, Fibiger HC: Regional topography within noradrenergic locus coeruleus as revealed by retrograde transport of horseradish peroxidase. I Comp Neurol 1979, 187:703-724.

46. Loughlin SE, Foote SL, Bloom FE: Efferent projections of nucleus locus coeruleus: topographic organization of cells of origin demonstrated by three-dimensional reconstruction. Neuroscience 1986, 18:29|-306.

47. Altman J, Bayer SA: Development of the brain stem in the rat. IV. Thymidine-radiographic study of the time of origin of neurons in the pontine region. J Comp Neurol 1980, 194:905-929.

48. Schlumpf M, Shoemaker WJ, Bloom FE: Innervation of embryonic rat cerebral cortex by catecholamine-containing fibers. J Comp Neurol 1980, 192:361-376.

49. Lauder JM, Bloom FE: Ontogeny of monoamine neurons in the locus coeruleus, Raphe nuclei and substantia nigra of the rat. I. Cell differentiation. J Comp Neurol 1974, I 55:469-48I.

50. Specht LA, Pickel VM, Joh TH, Reis DJ: Light-microscopic immunocytochemical localization of tyrosine hydroxylase in prenatal rat brain. II. Late ontogeny. J Comp Neurol I98I, 199:255-276.

51. Meyer JS, Shearman LP, Collins LM, Maguire RL: Cocaine binding sites in fetal rat brain: implications for prenatal cocaine action. Psychopharmacology (Berl) 1993, I I 2:445-45 I.

52. Booze RM, Lehner AF, Wallace DR, Welch MA, Mactutus CF: Doseresponse cocaine pharmacokinetics and metabolite profile following intravenous administration and arterial sampling in unanesthetized, freely moving male rats. Neurotoxicol Teratol 1997, 19:7-I5.

53. Evans SM, Cone EJ, Henningfield JE: Arterial and venous cocaine plasma concentrations in humans: relationship to route of administration, cardiovascular effects and subjective effects. J Pharmacol Exp Ther 1996, 279: 1345-1356.

54. Mactutus CF, Booze RM, Dowell RT: The influence of route of administration on the acute cardiovascular effects of cocaine 
in conscious unrestrained pregnant rats. Neurotoxicol Teratol 2000, 22:357-368.

55. Fischman MW, Schuster CR: Cocaine self-administration in humans. Fed Proc 1982, 4I:24I-246.

56. Bradford MM: A rapid and sensitive method for the quantitation of microgram quantities of protein utilizing the principle of protein-dye binding. Anal Biochem 1976, 72:248-254.

57. Paxinos $G$, Watson $C$ : The rat brain in stereotaxic coordinates. 4th edition. New York: Academic Press; 1998.

58. Koelle GB: The histochemical differentiation of types of cholinesterases and their localizations in tissues of the cat. J Pharmacol Exp Ther 1950, 100:158-179.

59. Unnerstall JR, Kopajtic TA, Kuhar MJ: Distribution of alpha 2 agonist binding sites in the rat and human central nervous system: analysis of some functional, anatomic correlates of the pharmacologic effects of clonidine and related adrenergic agents. Brain Res 1984, 319:69-101.

60. Booze RM, Wallace DR: Dopamine D2 and D3 receptors in the rat striatum and nucleus accumbens: use of 7-OH-DPAT and [125I]-iodosulpride. Synapse 1995, 19:1-13.

61. Geary WA, Wooten GF: Quantitative film autoradiography of opiate agonist and antagonist binding in rat brain. J Pharmacol Exp Ther 1983, 225:234-240.

62. Winer BJ: Statistical principles in experimental design. 2nd edition. New York: McGraw-Hill; 1971.

63. Greenhouse SW, Geiser S: On methods in the analysis of profile data. Psychometrika 1959, 24:95-II2.

Publish with Bio Med Central and every scientist can read your work free of charge

"BioMed Central will be the most significant development for disseminating the results of biomedical research in our lifetime. "

Sir Paul Nurse, Cancer Research UK

Your research papers will be:

- available free of charge to the entire biomedical community

- peer reviewed and published immediately upon acceptance

- cited in PubMed and archived on PubMed Central

- yours - you keep the copyright 